\title{
Pregnancy, lactation and the oestrous cycle of the pouched mouse, Saccostomus campestris
}

\author{
Lilian M. Westlin-van Aarde \\ Mammal Research Institute, University of Pretoria 0002, South Africa
}

\begin{abstract}
Summary. The anatomy and histology of pouched mouse ovaries were studied during the oestrous cycle, pregnancy and lactation along with the relationship between the ovarian structures and circulating concentrations of progesterone.

The structure of the ovaries resembled that of most rodents. Follicular development indicated that ovulation takes place on the night between pro-oestrus and oestrus, i.e. at the time when mating normally occurs. Corpora lutea were accumulating in cyclic females, while successively disappearing during pregnancy, leaving only the set formed after conception. After parturition luteal regression was rapid. Theca interna, included in the corpora lutea, formed glandular stromal tissue after regression of the luteal tissue formed from granulosa cells.

The progesterone profile of non-pregnant females indicated a short but functional luteal phase (peak at metoestrus) during the cycle. During pregnancy three peaks of progesterone stood out: (1) when implantation starts, (2) when older sets of corpora lutea showed rejuvenation and placental signs were found in the vaginal smears, and (3) 3 days before expected parturition when luteal development (as judged by histology) reached a peak.

The placenta may participate in but not 'take over' the progesterone production during later stages of pregnancy. Very low concentrations of peripheral progesterone during lactation and a very low level of follicular development at that time support an earlier suggestion of a lactational anoestrus in pouched mice.
\end{abstract}

Keywords: pouched mice; pregnancy, lactation; cycle; ovaries; progesterone

\section{Introduction}

Published information on the physiology of reproduction in African small rodents is scarce in comparison to what is available on rodents from other continents. Pouched mice (Saccostomus campestris) belong to the subfamily Cricetomyinae (Cricetidae), which comprises 3 species, all of them occurring exclusively in Africa. They are nocturnal, burrow-living rodents (Smithers, 1983), and probably lead a solitary life (Westlin-van Aarde, 1989). The females are spontaneous ovulators with a 4-day cycle and they do not appear to have a luteal phase. The corpora lutea formed during the cycle are pale and much smaller than those formed during pregnancy. There is no post-partum oestrus and the females are not reproductively active during lactation (Westlin-van Aarde, 1988).

The present study reports on the anatomy and histology of pouched mouse ovaries during the oestrous cycle, pregnancy and lactation and the relationship between the presence of ovarian structures and circulating concentrations of progesterone.

\section{Materials and Methods}

Animals. The pouched mice were bred at the Mammal Research Institute, University of Pretoria, South Africa, and maintained under optimal breeding conditions in a constant environment as described by Westlin-van Aarde (1988). 
Females were weaned at 25 days of age and housed in single-sex groups of 5 animals per cage. When 60 days old the females were exposed to 1 of 2 treatments: (a) housed singly; vaginal smears taken twice daily for at least 36 days, or (b) paired with a male of proven fertility; vaginal smears were taken each morning to confirm mating and pregnancy (see Westlin-van Aarde, 1988). Once pregnancy was confirmed in a female, the male was removed.

Ovaries and adrenals. Animals $(\mathrm{N}=250)$ were killed during the oestrous cycle, pregnancy or lactation (in the morning); 5 animals on each day of the cycle $(\mathrm{N}=20)$, in pregnancy $(\mathrm{N}=105)$ and in lactation $(\mathrm{N}=125))$ and ovaries and adrenals were dissected out and weighed fresh. The ovaries were fixed in Bouin's fluid, routinely prepared for light microscopy, serially sectioned at $5 \mu \mathrm{m}$ and stained with a tetrachrome combination according to Borg $e t a l$. (1978).

Blood samples. Blood samples $(0.6 \mathrm{ml} / \mathrm{sample})$ were collected in heparinized tubes by cardiac puncture between 09:00 and 11:00 $\mathrm{h}$ from ether-anaesthetized females $(\mathrm{N}=250)$. The samples were taken during the oestrous cycle $(\mathrm{N}=20)$ or throughout pregnancy $(\mathrm{N}=105)$ and lactation $(\mathrm{N}=105)$ at 5 -day intervals. To obtain samples from each day of the reproductive stages, sampling started on different days of the cycle (oestrus, metoestrus, dioestrus or pro-oestrus) and pregnancy (Day 1, 2, 3, 4 or 5) in different females. Samples from 5 females, suspected as being pseudopregnant (Day 9; acyclic vaginal smears but no weight-gain) were also included. Blood was centrifuged for $15 \mathrm{~min}$ and plasma was removed and stored at $-20^{\circ} \mathrm{C}$ until assayed. (To avoid iron deficiency during serial blood sampling, the animals were given lettuce every day.)

Radioimmunoassay of progesterone. The procedure was, with minor modifications, similar to that of van Aarde (1985). Plasma was extracted from duplicate plasma samples $(0.1 \mathrm{ml}$ in non-pregnant females and $0.1 \mathrm{ml}$ of a 10 times diluted sample in pregnant females).

A series of standards containing $31 \cdot 2,62 \cdot 5,125,250,500,1000$ and $2000 \mathrm{pg}$ progesterone $/ 0 \cdot 1 \mathrm{ml}$ phosphate buffer was prepared in duplicate and included in each assay. Duplicate water (glass-distilled) blanks and dried residues of ether only were included in each assay. Antiserum to progesterone (1522; supplied by R. P. Millar, Department of Chemical Pathology, University of Cape Town, South Africa) was added to plasma extracts, water blanks, ether blanks and standards at a 1:4000 dilution in phosphate buffer and mixed. $\left[1,2,6,7-{ }^{3} \mathrm{H}\right]$ Progesterone (sp. act. $96 \mathrm{Ci} /$ mmol: Radiochemical Centre, Amersham, Bucks, UK) in phosphate buffer was added to each tube, and the contents were mixed and incubated.

After separation of the progesterone bound to the antibody from the free steroid, scintillation fluid was added to each vial (Ready Solve Hb/b: Beckman Instruments (Pty) Ltd, Johannesburg, South Africa), and the radioactivity was counted at least $4 \mathrm{~h}$ later for $2 \mathrm{~min}$, using a Packard 1500 Tri-carb $^{\circledast}$ Liquid Scintillation Analyzer.

The recovery of known amounts $\left(\sim 10000\right.$ c.p.m.) of $\left[1,2,6,7-{ }^{3} \mathrm{H}\right]$ progesterone in phosphate buffer to which $0 \cdot 1 \mathrm{ml}$ pooled plasma had been added served to determine procedural losses incurred during extraction.

Validations. The specificity of the antiserum (1522) was quantified by the supplier (see above) and cross-reactions of other steroids were: $11 \alpha$-hydroxyprogesterone, $26 \cdot 2 \% ; 11 \beta$-hydroxyprogesterone, $48 \cdot 3 \% ; 5 \alpha$-pregnane-3,20-dione, $25.1 \%$; $17 \alpha$-hydroxyprogesterone, $2.6 \%$; pregnenolone, $5 \cdot 2 \%$; 11 -deoxycorticosterone, $1.9 \%$; 11 -deoxycortisol $1.7 \%$; $3 \alpha$-hydroxy-5-pregnane-20-one, $0.4 \% ; 20 \alpha$-hydroxy-4-pregnane-3-one, $0 \cdot 3 \%$; cortisol, $<0 \cdot 1 \%$. Cross-reactions of testosterone, 4-androstenedione, oestradiol- $17 \beta$ and oestrone were all $<0.001 \%$.

Detection limit of the assays, determined through the use of SECURIA 2200 (Packard Instrument Co, Downers Grove, IL, USA), ranged from $26 \cdot 3$ to $156.0 \mathrm{pg} / \mathrm{ml}$ (mean $93.5 \pm 52.4 \mathrm{pg} / \mathrm{ml} ; n=12$ ). The 24 blanks containing glassdistilled water or nothing, measured during the assays, contained $0.11 \pm 0.22 \mathrm{ng}$ progesterone equiv. $/ \mathrm{ml}$.

Recovery estimates varied from 68.0 to $91 \cdot 1 \%$ (mean $82.9 \% \pm 9.07 ; n=6$ ) for samples obtained from pregnant females and from $63 \cdot 2$ to $69 \cdot 2 \%$ (mean $66.5 \% \pm 2 \cdot 47 ; n=5$ ) for samples obtained from non-pregnant, lactating females. The recovery estimate for samples obtained from non-pregnant, cyclic females was $81 \cdot 27 \%(n=1)$. Results were corrected accordingly. Intra-assay coefficient of variation was $4.99 \%$, and inter-assay coefficient of variation for samples of pregnant and non-pregnant lactating females were $13.9(n=6)$ and $12.7 \%(n=5)$ respectively (samples of non-pregnant, cyclic females were all included in 1 assay).

\section{Results}

\section{Ovaries}

The macroscopic appearance of the ovaries was similar to that of many other rodents, being enclosed in a capsule and with corpora lutea protruding from the surface. Primary oocytes were observed just beneath a thin tunica albuginea, and primordial follicles occurred only in the peripheral zone of the cortex.

Mean ovarian weights of pregnant females were not correlated to gestational age $(r=0 \cdot 53)$ or to progesterone concentrations $(r=0.38)$ and did not differ significantly from those of cyclic 
females (see Table 1a). The ovarian weights gradually declined during the first 5 days of lactation and remained low for the rest of the lactating period. The mean ovarian weights of all lactating females were significantly lower than those of pregnant females (see Table 1a).

Table 1. Mean ovarian (a) and adrenal (b) weights of cyclic, pregnant and lactating female pouched mice

\begin{tabular}{|c|c|c|c|c|c|}
\hline & & \multirow{2}{*}{$\begin{array}{l}\text { No. of } \\
\text { females }\end{array}$} & \multirow{2}{*}{$\begin{array}{l}\text { No. of } \\
\text { organs }\end{array}$} & \multicolumn{2}{|c|}{ Organ weight (mg) } \\
\hline & & & & Mean & s.d. \\
\hline \multicolumn{6}{|l|}{ (a) Ovaries } \\
\hline Cyclic & & 27 & 54 & $89 \cdot 0$ & $31 \cdot 24^{*}$ \\
\hline Pregnant & & 61 & 122 & $101 \cdot 3$ & $26 \cdot 17 \dagger$ \\
\hline Lactating & d. $1-5$ & 10 & 20 & $46 \cdot 3$ & 23.49 \\
\hline Lactating & d. $6-25$ & 36 & 72 & $19 \cdot 4$ & 3.94 \\
\hline Lactating & d. $1-25$ & 46 & 92 & $27 \cdot 0$ & $7 \cdot 24^{*} \dagger$ \\
\hline \multicolumn{6}{|l|}{ (b) Adrenals } \\
\hline Cyclic & & 31 & 62 & $32 \cdot 2$ & $9 \cdot 29$ \\
\hline Pregnant & & 60 & 120 & $29 \cdot 0$ & $6 \cdot 79 \ddagger$ \\
\hline Lactating & & 14 & 28 & $35 \cdot 8$ & $5 \cdot 58 \ddagger$ \\
\hline
\end{tabular}

Non-pregnant females. The ovaries of cyclic pouched mice were mainly occupied by luteal bodies in different developmental stages (including corpora albicantia) resulting from several subsequent ovulations. The number of corpora albicantia in an ovary (up to 21), indicated that there was more than one generation present. The different sets of corpora lutea (corpora albicantia excluded) could easily be distinguished from each other by the histological picture. The total number of luteal bodies varied between the cycles and between the animals, the largest number being 36 in a dioestrous female. No accessory corpora lutea were found in the ovaries of any of the cyclic females.

During the cycle, rather few follicles were found in the ovaries $(n=40, \mathrm{~N}=20)$, in most cases $(90 \%)$ about $10(8-12)$ small non-antral and about $10(7-12)$ antral follicles, regardless of the day of the cycle. The granulosa cell layer was still too thick and the antrum too small to consider them ready to rupture on the morning of pro-oestrus. The theca interna was hypertrophied around all follicles, eventually forming corpora atretica around the atretic ones. Luteinized thecal cells at the edge of corpora lutea eventually united and finally formed glandular-like tissue around the corpora albicantia. Theca externa was never prominent. The remaining tissue in the ovaries comprised vascularization and very little stromal tissue with a glandular appearance.

Pregnant females. During early pregnancy there were several sets of corpora lutea in the ovaries. The set formed after conception successively developed in size and degree of luteinization, while earlier sets successively regressed. Theca interna was luteinized and included in the corpora lutea of pregnancy as in cyclic females (see above). At Day 13-15, the 2 youngest sets of corpora lutea were equally well luteinized and besides them only very old corpora albicantia were observed. From then on, the second youngest set of corpora lutea started to regress, while the corpora lutea of pregnancy continued to develop throughout pregnancy.

An accessory corpus luteum (i.e. an unovulated luteinized follicle) was found only in one female, at Day 18 of pregnancy.

The follicular development was very moderate during pregnancy. Early antral follicles underwent rapid atresia, the thecal glands then forming corpora atretica. 
As the corpora lutea from earlier ovulations regressed, the luteinized theca cells (see above) maintained their glandular structure and filled a lot of the interstitial space up to Day 19 of pregnancy, but no such tissue was observed after that day.

The histology of the ovaries of pseudopregnant females (Day 9; $N=5$ ) agreed well with that of ovaries of pregnant females on Day 9, in terms of number, size and development of corpora lutea, follicular development and appearance of stromal tissue.

Lactating females. From Day 3 of lactation, the corpora lutea of pregnancy started to regress. From Day 5 regression was rapid and from Day 17 until 3 days after weaning (i.e. Day 28) only 1 set of corpora albicantia was present. From Day 12 of lactation, primordial follicles frequently started to occur, increasing in numbers from Day 16, but not until 3 days after lactation were Graafian follicles with thecal glands present. Corpora atretica were few during this period.

\section{Adrenals}

Mean adrenal weights of cyclic and pregnant females were similar (see Table lb). Mean adrenal weights of lactating females, however, were significantly greater than those of pregnant females, although similar to those of cyclic females. There was no significant correlation between adrenal weight and gestational age $(r=0 \cdot 12)$.

\section{Placental sign}

During pregnancy, blood occurred in the vaginal smears from Day 8 to Day 20, with $80 \%$ occurring between Days 13 and $16(\mathrm{~N}=55)$.

\section{Circulating progesterone}

Temporal changes in concentration of circulating progesterone during the oestrous cycle and pregnancy are presented in Fig. 1. During the cycle, plasma concentrations of progesterone increased to a significant peak of about $12 \mathrm{ng} / \mathrm{ml}$ (mean $12.11 \mathrm{ng} / \mathrm{ml}$, s.d. $=6.43 ; \mathrm{N}=8$ ) at metoestrus (Fig. 1a; Day 2).

On Day 1 (=oestrus), the progesterone values were significantly higher in fertilized females than in cyclic (unmated) females (mean $7.66 \mathrm{ng} / \mathrm{ml}$, s.d. $=0.55 ; \mathrm{N}=5 ;$ and mean $4.19 \mathrm{ng} / \mathrm{ml}$, s.d. $=1.362 ; \mathrm{N}=9$, respectively) $(t=6.223$, d.f. $=9 ; P<0.001)$. On the next day (=metoestrus), fertilized females showed a higher increase of progesterone concentrations (mean $42.60 \mathrm{ng} / \mathrm{ml}$, s.d. $=13.87 ; \mathrm{N}=6$ ) than did cyclic females (see above) $(t=4.997$, d.f. $=7 ; P<0.01)$. During pregnancy, there were 3 significant peaks of progesterone concentrations: Days 5-8, Day 13 and Day 17. After parturition, plasma values of progesterone dropped to $\sim 0 \mathrm{ng} / \mathrm{ml}$ (below the assay sensitivity). During lactation, the progesterone concentrations ranged from 0 to $0.28 \mathrm{ng} / \mathrm{ml}$, mostly being below the sensitivity of the assay (mean detection limit $=0.09 \mathrm{ng} / \mathrm{ml}$ ). During the first 4 days after the end of lactation (young were removed), the concentration of circulating progesterone remained low, mostly under the detection limit for the assay, but with a larger range $(0-9.09 \mathrm{ng} / \mathrm{ml})$.

Five pseudopregnant females at Day 9 had significantly higher progesterone concentrations (mean $210.28 \mathrm{ng} / \mathrm{ml}$, s.d. $=59.73$ ) than did pregnant females at Day 9 (mean $79.18 \mathrm{ng} / \mathrm{ml}$, s.d. $=48 \cdot 11 ; \mathrm{N}=6)(t=3 \cdot 646$, d.f. $=9 ; P<0 \cdot 01)$.

\section{Discussion}

The larger size of antral follicles on the day of pro-oestrus than on the day before or after, while still not ready to rupture, suggests that ovulation takes place between pro-oestrus and oestrus, i.e. at about the time when the animals normally mate (Westlin-van Aarde, 1988). 


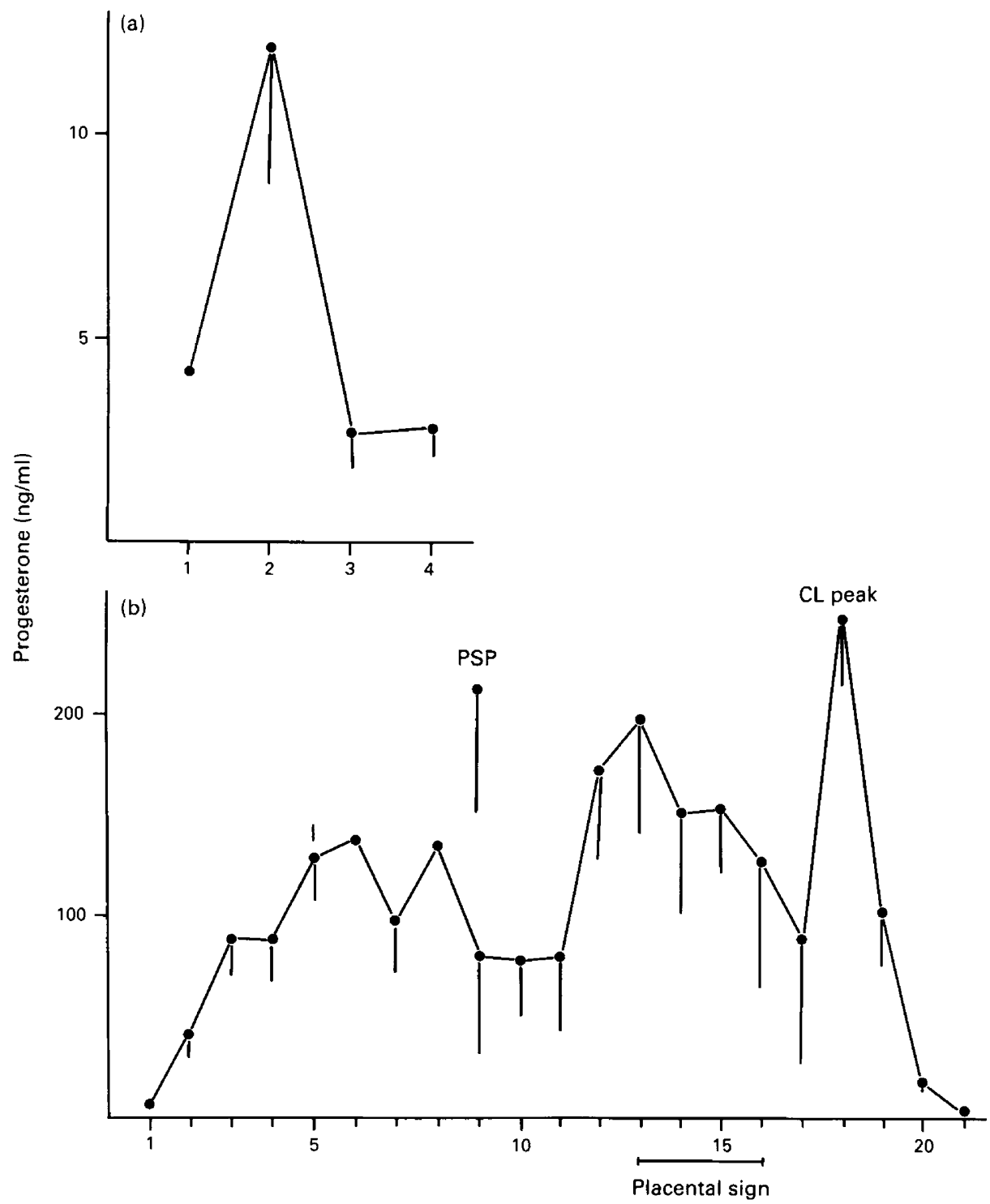

Fig. 1. Temporal changes in concentration of circulating progesterone in pouched mice during (a) the oestrous cycle and (b) pregnancy. Results are presented as the mean of 5 animals with the s.d. indicated by the vertical bars. Day $1=$ oestrus. I = start of implantation; PSP = pseudopregnant females.

Mice and rats have a short luteal phase during the cycle, and there is an accumulation of corpora lutea in the ovaries (see Asdell, 1964; Rowlands \& Weir, 1984). In hamsters, however, the corpora lutea do not accumulate in cyclic females, although they have a short (Grady \& Greenwald, 1968; Greenwald, 1968; Kent, 1968) but functional luteal phase (Lukaszewska \& Greenwald, 1970; Leavitt et al., 1973). The pouched mice in the present study showed an accumulation of corpora lutea during the cycle, and although the histological appearance during metoestrus indicated a low activity of the glands, peak peripheral concentrations of progesterone at that time suggest a short but functional luteal phase during the oestrous cycle in this species.

The significance of a progesterone peak during the oestrous cycle, when no mating has 
occurred, may be to prime the reproductive tract for implantation. The significantly higher levels of progesterone in conceiving females at the time of mating and the day after ( = metoestrus) than during oestrus and metoestrus in cyclic females, suggests that priming of the reproductive tract by progesterone may be required for conception.

Rats (Barraclough et al., 1971; Smith et al., 1975) experience a progesterone peak (>50 ng/ml) during pro-oestrus. Studies on hamsters are contradictory. Leavitt \& Blaha (1970) demonstrated the lowest levels of progesterone $(\sim 1 \mathrm{ng} / \mathrm{ml})$ during the cycle at pro-oestrus, while Saidapur \& Greenwald (1978) found a pregesterone peak (11-18 ng/ml) during that stage and also suggested that the interstitial tissue is one of the primary sources for that peak (Saidapur \& Greenwald, 1979). The progesterone concentrations in cyclic pouched mice of the present study were lowest during dioestrus and pro-oestrus $(\sim 2.5 \mathrm{ng} / \mathrm{ml})$, although the interstitial tissue at that stage was as glandular (judged from the histology) as during the rest of the cycle and during pregnancy.

The similarity of mean ovarian weights between cyclic and pregnant females (regardless of stage) could be ascribed to the accumulation of corpora lutea during the cycle, while during pregnancy the earlier sets regressed as the luteal set of pregnancy developed. After parturition, weight decrease of the ovaries coincided with luteal regression.

Although ovarian weights of pregnant females were not correlated to gestational age or to peripheral progesterone concentrations, the development of corpora lutea (size and degree of luteinization) in these females agreed with the increase of peripheral progesterone concentrations during pregnancy, but not with the peaks. The first progesterone peak coincided with the time when implantation starts (Westlin-van Aarde, 1988). The second peak (on Day 13) was not accompanied by any visible change in development of the corpora lutea of pregnancy. However, on Days 13-15, the 2 sets of equally well luteinized corpora lutea, only differing in size, suggests a temporary rejuvenation of the youngest set of corpora lutea formed before conception. Furthermore, the time when the progesterone peak and the rejuvenation of an older set of corpora lutea occurred coincided with the time (Days 13-16) when blood in the vaginal smears was observed in most $(80 \%)$ pregnant females. This blood originates from a leakage of red blood cells from the placenta, the placental sign, which has been observed in a number of rodents, e.g. a gerbil (Tatera brantsi), the multimammate rat (Rattus coucha), a subspecies of the wild mouse (Mus musculus molossinus), and the laboratory mouse (see Asdell, 1964).

On Day 18 of pregnancy, when the third peak of progesterone concentration occurred, no such rejuvenation of older corpora lutea was observed. On that day, however, cell size and degree of luteinization of the corpora lutea of pregnancy had markedly increased. The events above suggest that, as in hamsters (Hilliard, 1973), the placenta may participate in progesterone production in pouched mice during the later stages of pregnancy, but not 'take over' the production as in rats, guinea-pigs and sheep (see Rowlands \& Weir, 1984). Whether the placenta actually has a luteotrophic role in pouched mice, as in rats, mice and guinea-pigs (Greenwald, 1967), was not established. The occurrence of one accessory corpus luteum in a pregnant female on Day 18 was considered incidental.

The progesterone profile during pregnancy in pouched mice, with 3 distinct peaks increasing in size with gestation time, resembles the progesterone profile of pregnant hamsters (Leavitt \& Blaha, 1970), while differing from that of mice, in which the progesterone concentrations reach a 'fluctuating plateau' on Day 5-6 of pregnancy, which declines from Day 17 (McCormack \& Greenwald, 1974). It also differed from the profile in rats in which the concentration of progesterone is doubled between Days 7 and 13 but recedes 2 or 3 days before parturition (see Rowlands \& Weir, 1984).

The very low levels of follicular development and progesterone concentrations throughout lactation support an earlier suggestion of the occurrence of a lactational anoestrus in pouched mice (as indicated by vaginal smears) (Westlin-van Aarde, 1988). This is unlike most other myomorph rodents, but well in agreement with the hamster (see Rowlands \& Weir, 1984).

The significantly high concentration of progesterone in the pseudopregnant females (Day 9) than in females at Day 9 of pregnancy could not be explained. 
An increase in adrenal weight in sexually active females has been described in a number of cricetids, for instance Clethrionomys glareolus (Delost \& Delost, 1954; Andersson et al., 1978), C. rutilus (Sealander, 1967), Microtus montanus (McKeever, 1959), M. agrestris (Chitty, 1961; Chitty \& Clarke, 1963) and $M$. pennsylvanicus (Christian \& Davies, 1966). The increase in adrenal weight in $M$. agrestis, C. glareolus (Jorné-Safriel, 1968; Chitty \& Clarke, 1963) and Dicrostonyx groenlandicus (Hasler \& Banks, 1975) has been shown to take place during pregnancy, and a relation between fertility and adrenal growth after mating was demonstrated in $C$. glareolus (Andersson \& Gustafsson, 1981). Such a relation was not found in the present study. The significant increase in weight of the adrenals in lactating females may be ascribed to stress, as it is known that female pouched mice are very aggressive just after parturition (Westlin-van Aarde, 1988).

The University of Pretoria and the Foundation for Research Development provided financial support. I thank Professor R. J. van Aarde for the assistance and advice during the assay work.

\section{References}

Andersson, B. \& Gustafsson, T. (1981) Relation between fertility and adrenal growth after mating in the bank vole, Clethrionomys glareolus. Can. J. Zool. 59, 329-331.

Andersson, B., Gustafsson, T., Meurling, P. \& Nyholm, E. (1978) The role of the adrenal cortex in reproduction in the female bank vole, Clethrionomys glareolus. In Comparative Endocrinology, p. 83. Eds P. J. Gaillard \& H. H. Boer. Elsevier/North Holland, Amsterdam.

Asdell, S.A. (1964) Patterns of Mammalian Reproduction, 2nd edn. Cornell University Press, Ithaca.

Barraclough, C.A., Collu, R., Massa, R. \& Martini, L. (1971) Temporal interrelationships between plasma LH, ovarian secretion rates, and peripheral plasma progestin concentrations in the rat: effects of nembutal and exogenous gonadotropins. Endocrinology 88, 1437-1447.

Borg, B., Andersson, M. \& Meurling, P. (1978) The biology of the wild rabbit, Oryctolagus cuniculus, in southern Sweden. III. Histology of the uterus in the non-breeding season. Acta zool., Stockh. 59, 253-260.

Chitty, H. (1961) Variation in the weight of the adrenal glands of the field vole, Microtus agrestis. J. Endocr. 22, 387-393.

Chitty, H. \& Clarke, J.R. (1963) The growth of the adrenal glands of laboratory and field voles and changes in it during pregnancy. Can. J. Zool. 41, 1025-1034.

Christian, J.J. \& Davies, D.E. (1966) Adrenal glands in female voles (Microtus pennsylvanicus) is related to reproduction and population size. J. Mammal. 47, $1-18$.

Delost, P. \& Delost, H. (1954) Existence d'une zone X surrénalienne chez le Campagnol roussatre (Clethrionomys glareolus S.) C. r. Séanc. Soc. Biol. 148, $1788-1791$.

Grady, K.L. \& Greenwald, G.S. (1968) Gonadotropic induction of pseudopregnancy in the cyclic hamster. Endocrinology 83, 1173-1180.

Greenwald, G.S. (1967) Luteotropic complex in the hamster. Endocrinology 80, 118-130.

Greenwald, G.S. (1968) Failure of hypophysectomy to affect regression of cyclic hamster corpus luteum. $J$. Reprod. Fert. 16, 495-497.
Hasler, J.F. \& Banks, E.M. (1975) Morphological changes in the ovaries and other organs of the collared lemming (Dicrostonyx groenlandicus) during pregnancy and pseudopregnancy. Can. J. Zool. 53, 12-18.

Hilliard, J. (1973) Corpus luteum function in guineapigs, hamsters, rats, mice and rabbits. Biol. Reprod. 8, 203-221.

Jorné-Safriel, O. (1968) Some factors affecting the adrenal juxtamedullary zone in the vole, Microtus agrestis and bank vole, Clethrionomys glareolus. Ph.D. thesis, Oxford University.

Kent, G.C., Jr (1968) Physiology of reproduction. In The Golden Hamster, p. 119. Eds R. A. Hoffman, P. F. Robinson \& H. Magalhaes. Iowa State University Press, Ames.

Leavitt, W.W. \& Blaha, G.C. (1970) Circulating progesterone levels in the golden hamster during the estrous cycle, pregnancy and lactation. Biol. Reprod. 3, 353-361.

Leavitt, W.W., Basom, C.R., Bagwell, J.N. \& Blaha, G.C. (1973) Structure and function of the hamster corpus luteum during the estrous cycle. Am.J. Anat. 136, 235-250.

Lukaszewska, J.H. \& Greenwald, G.S. (1970) Progesterone levels in the cyclic and pregnant hamster. Endocrinology 86, 1-9.

McCormack, J.T. \& Greenwald, G.S. (1974) Progesterone and oestradiol-17ß concentrations in the peripheral plasma during pregnancy in the mouse. J. Endocr. 62, 101-207.

McKeever, S. (1959) Effects of reproductive activity on the weight of adrenal glands in Microtus montanus. Anat. Rec. 135, 1-5.

Rowlands, I.W. \& Weir, B.J. (1984) Mammals: nonprimate eutherians. In Marshall's Physiology of Reproduction, Reproductive Cycles of Vertebrates, 4th edn, vol. 1, pp. 455-658. Ed. G. E. Lamming. Churchill Livingstone, Edinburgh.

Saidapur, S. \& Greenwald, G.S. (1978) Peripheral blood and ovarian level of sex steroids in the cyclic hamster. Biol. Reprod. 18, 401-408.

Saidapur, S.D. \& Greenwald, G.S. (1979) Antral follicular and interstitial contributions to progesterone 
secretion in the proestrous hamster. In Ovarian Follicular and Corpus Luteum Function, pp. 245-247. Eds C. P. Channing, J. M. Marsh \& W. A. Sadler. Plenum Press, New York.

Sealander, J.A. (1967) Reproductive status and adrenal size in the northern red-backed vole in relation to season. Int. J. biometeorol. 11, 213-220.

Smith, M.S., Freeman, M.E. \& Neill, J.D. (1975) The control of progesterone secretion during the estrous cycle and early pseudopregnancy in the rat: prolactin, gonadotrophin and steroid levels associated with rescue of the corpus luteum of pseudopregnancy. Endocrinology 96, 219-226.
Smithers, R.H.N. (1983) The Mammals of the Southern African Subregion. University of Pretoria, Pretoria.

van Aarde, R.J. (1985) Circulating progesterone and oestradiol-17 $\beta$ concentrations in cyclic Cape porcupines, Hystrix africaeaustralis. J. Reprod. Fert. 75, 583-591.

Westlin-van Aarde, L.M. (1988) Reproduction in a laboratory colony of the pouched mouse, Saccostomus campestris. J. Reprod. Fert. 83, 773-778.

Westlin-van Aarde, L.M. (1989) Social environment and reproduction in female pouched mice, Saccostomus campestris. J. Reprod. Fert. 86, 367-372.

Received 12 December 1988 